\title{
Protein S Activity Actual to Control Ratio Measurement
}

National Cancer Institute

\section{Source}

National Cancer Institute. Protein S Activity Actual to Control Ratio Measurement. NCI

Thesaurus. Code C147424.

The determination of the ratio of the biological activity of protein $\mathrm{S}$ in a subject's

specimen when compared to the same activity in a control specimen. The measurement may be expressed as a ratio or percentage. 